Page 1 of 2 Proj.

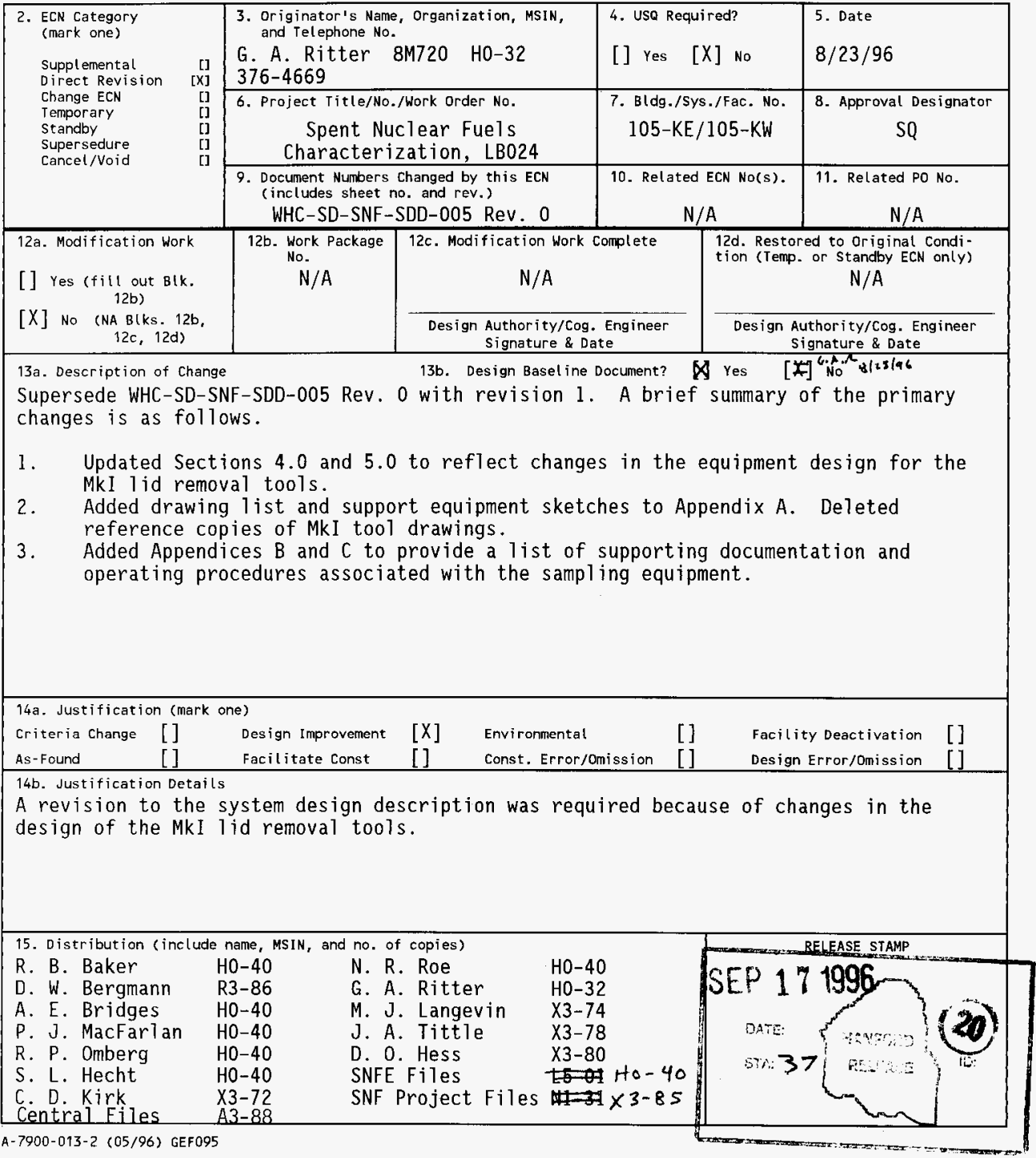




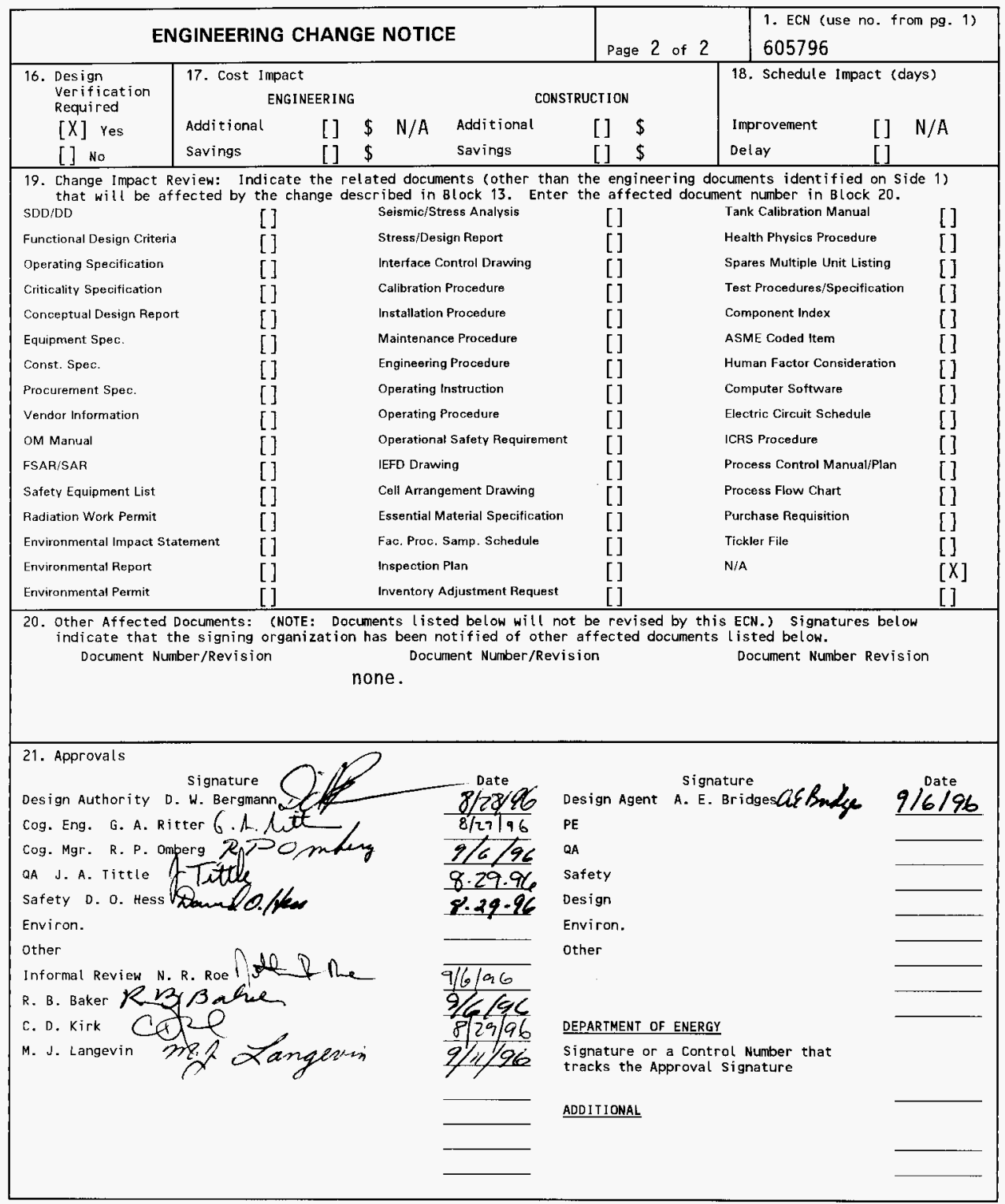




\section{System Design Description for Sampling Fuel in K Basins}

Gienn A. Ritter

West inghouse Hanford Company, Richland, WA 99352

U.S. Department of Energy Contract DE-AC06-87RL10930

$\begin{array}{lll}\text { EDT/ECN: } & 604988 & \text { UC: } 2070 \\ \text { Org Code: } & 8 M 720 & \text { Charge Code: }{ }^{2 B 024} \\ \text { B\&R Code: } & \text { EW3135040 } & \text { Total Pages: } 40\end{array}$

Key Words: K Basins, Sampling Equipment, Fuel Characterization, System Design Description, Spent Nuclear Fuel Project

Abstract: This System Design Description provides: (1) statements of the Spent Nuclear Fuel Project's needs for sampling of fuel in the $K$ East and $K$ West Basins, (2) the sampling equipment functions and requirements, (3) a general work plan and the design logic followed to develop the equipment, and (4) a summary description of the design for the sampling equipment. This report summarizes the integrated application of both the subject equipment and the canister sludge sampling system in the characterization campaigns at $K$ Basins.

TRADEMARK DISCLAIMER. Reference herein to any specific commercial product, process, or service by trade name, trademark, manufacturer, or otherwise, does not necessarily constitute or imply its endorsement, recommendation, or favoring by the United States Government or any agency thereof or its contractors or subcontractors.

Printed in the United States of America. To obtain copies of this document, contact: WHC/BCS Document Control Services, P.O. Box 1970, Mailstop H6-08, Richland WA 99352, Phone (509) 372-2420; Fax (509) 376-4989.
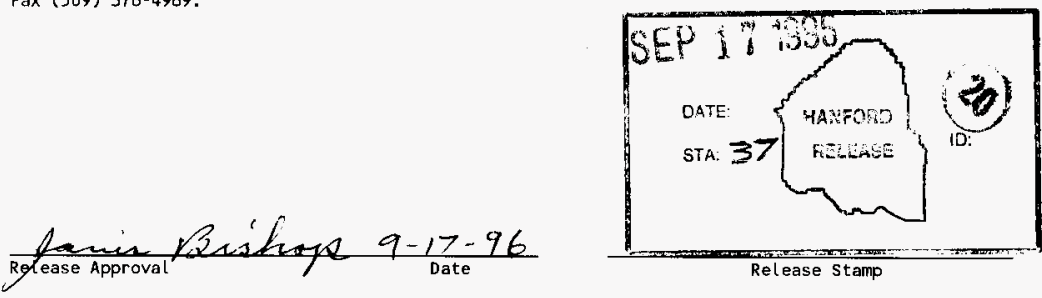
(2) Title

System Design Description for Sampling Fuel in $\mathrm{K}$ Basins

CHANGE CONTROL RECORD

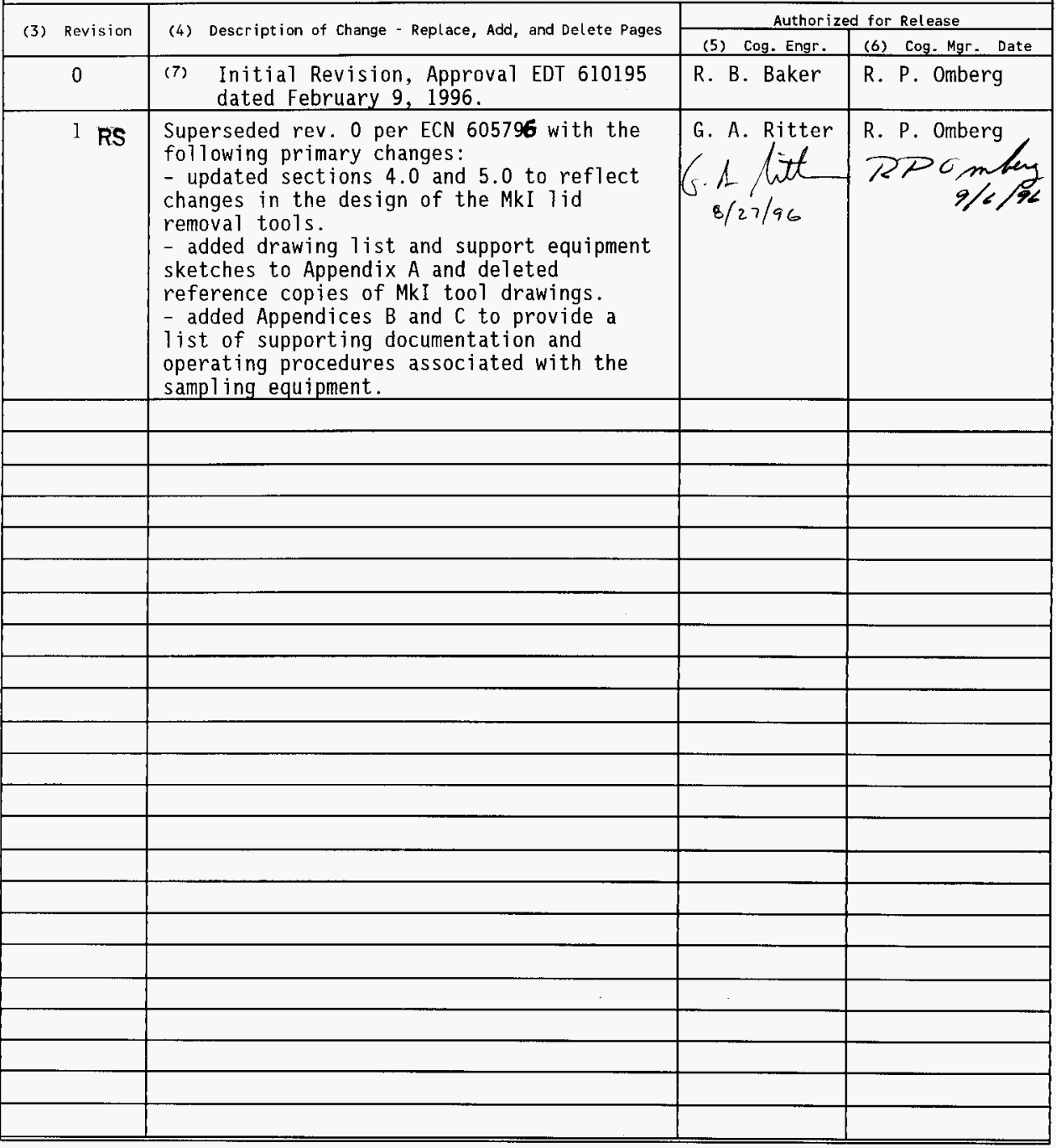


WHC-SD-SNF-SDD-005 Rev. 1

\section{CONTENTS}

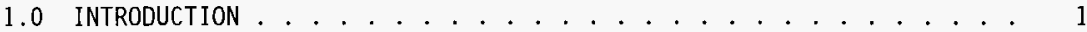

1.1 DEFINITIONS . . . . . . . . . . . . . . 1

1.2 PROJECT BASIS OF NEED FOR SAMPLING SYSTEM . . . . . . . 1

2.0 FUNCTIONS AND REQUIREMENTS ................... 2

2.1 FUNCTIONS . . . . . . . . . . . . . . . . . . . . . . . . . . 2

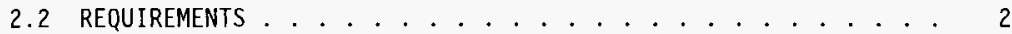

3.0 GENERAL WORK PLAN AND $\mathrm{K}$ BASIN PLANT INTERFACES . . . . . . . . . 3

4.0 SYSTEM DESIGN DESCRIPTION . . . . . . . . . . . . . . . . 4

5.0 SYSTEM OPERATION . . . . . . . . . . . . . . . . . . 8

6.0 SYSTEM LIMITATIONS, CASUALTY EVENTS, AND RESPONSE TO OFF-NORMAL

EVENTS . . . . . . . . . . . . . . . . . 10

6.1 MINOR OFF-NORMAL EVENTS . . . . . . . . . . . . . . . 10

6.2 SIGNIFICANT OFF-NORMAL EVENTS ............. 11

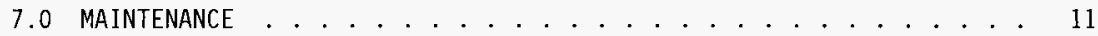

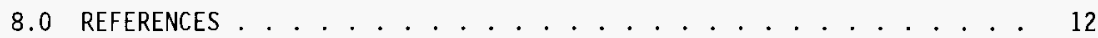

APPENDIX A - DRAWING LIST AND SUPPORT EQUIPMENT SKETCHES . . . . . . . . A-1

APPENDIX B - SUPPORTING DOCUMENTS . . . . . . . . . . . . B-1

APPENDIX C - OPERATING PROCEDURES ............... C-1 


\section{LIST OF FIGURES}

1. Overview of K Basin SNF Canister Contents and Path Forward . . . . . 17

2. Proposed K Basin Plant Review of Fuel Sampling System Development and Application . . . . . . . . . . . . . . . . . 18

3. Work Breakdown for Development and Application of K Bas in Fuel Sampling System . . . . . . . . . . . . . . . 19

4. K East Basin Process Flow..................... 20

5. K West Basin Process Flow.................... . . 21 
WHC-SD-SNF-SDD-005 Rev. 1

\section{LIST OF TABLES}

1. Documents Supporting Design and Application of

K Basin Fuel Sampling System . . . . . . . . . . . . . . . . 13

2. List of Primary Responsibilities . . . . . . . . . . . . . . . . . 14

3. Equipment and Functions . . . . . . . . . . . . . . . . . . . 15

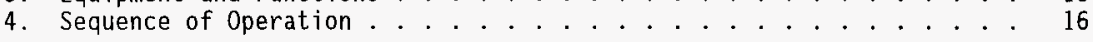




\section{LIST OF TERMS}

$\begin{array}{ll}\text { ALARA } & \text { As Low As Reasonably Achievable } \\ \text { CNS } & \text { Chem Nuclear Systems } \\ \text { DQO } & \text { Data Quality Objective } \\ \text { DOE-RL } & \text { Department of Energy Richland Field Office } \\ \text { HPT } & \text { Health Physics Technician } \\ \text { PIC } & \text { Person In Charge } \\ \text { POC } & \text { Point of Contact } \\ \text { SAP } & \text { Sample Analysis Plan } \\ \text { SAR } & \text { Safety Analysis Report } \\ \text { SOD } & \text { System Design Description } \\ \text { SFEC } & \text { Single fuel element container } \\ \text { SEP } & \text { Safety Evaluation for Packaging } \\ \text { SNF } & \text { Spent Nuclear Fuel } \\ \text { SNFE } & \text { Spent Nuclear Fuel Evaluations } \\ \text { SNFP } & \text { Spent Nuclear Fuels Project } \\ \text { USQ } & \text { Unreviewed Safety Question } \\ \text { WHC } & \text { Westinghouse Hanford Company }\end{array}$




\section{SYSTEM DESIGN DESCRIPTION FOR SAMPLING FUEL IN $K$ BASINS}

\subsection{INTRODUCTION}

A number of key activities underway as part of the Spent Nuclear Fuels Project (SNFP) are related to the processing and disposing of spent nuclear fuel (SNF) from the 105-K Basins (K Basins). The proposed "Path Forward" (Culley 1995) disposition of SNF is summarized in Figure 1 along with estimates of the quantities involved. Development of SNF recovery equipment, processing equipment, transport methods, and disposal options all require specific SNF characterization data.

While some data on SNF have been obtained, recent studies conclude there is less data than needed for project decisions and equipment design bases. Additional quality data are required and will be defined through the process of developing Data Quality Objectives (DQO) and Sample Analys is Plans (SAP). Because of the requirements for characterizing SNF in both $K$ East and $K$ West Basins, the SNF sampling system was developed to be used as a routine process run by Basin Operations. Application of the system will be under the cognizance of the Spent Nuclear Fuel Evaluations group who is tasked to provide characterization data for the SNFP.

Taking SNF samples is a comparatively simple task by Basin Operations standards and is basically considered an activity rather than a project. Based on discussions with Operations staff, a graded approach is being used for the requirements for $K$ Basin reviews as defined in the "K Basin Plant

Project Review Guidelines" (WHC 1996). Responding to this, this system design description (SDD) document addresses several documentation needs including:

(1) statements of the SNFP needs requiring this sampling, (2) system functions and requirements, (3) a general work plan and design logic being followed, and (4) a summary design description of the primary system including process flow. This SDD provides an integrated package for use with $K$ Basin staff and for interfacing with the design and support team.

\subsection{DEFINITIONS}

Fuel samples

Selected fuel elements and parts that will be shipped to the 327 Building (hot cells) for examination.

\subsection{PROJECT BASIS OF NEED FOR SAMPLING SYSTEM}

The system and equipment that is the subject of this SDD will be used to sample and ship spent nuclear fuel elements, broken fuel parts, and canister sludge to the 327 Building for examination. This activity is an integral part of the current SNFP characterization program plan (Siddoway 1995), which responded to the accelerated Path Forward Memorandum of Agreement (WHC 1995). 


\subsection{FUNCTIONS AND REQUIREMENTS}

\subsection{FUNCTIONS}

The system will provide the capability to safely and efficiently sample SNF from open and closed canisters located in the $K$ Basins. Included in the system are the tools to decap selected closed canisters in KW basin, remove selected fuel and sludge samples from open KE and KW canisters, to load the samples into an appropriate cask for delivery to the 327 Building for required analysis and characterization, and to recap canisters in $\mathrm{KW}$ basin. Also included in the system are tools to draw gas and liquid samples from closed canisters in the $\mathrm{KW}$ Basin without decapping.

The system will reliably provide fuel samples consistent with the DQ0 and SAP, will maintain traceability, and will minimize potential contamination in the $\mathrm{K}$ Basins and transportation path to the 327 Building.

The system will incorporate as many proven design features as possible from past fuel and sludge sampling experience and will incorporate features to eliminate or reduce previously encountered problems.

\subsection{REQUIREMENTS}

The following summarize the system requirements:

A. The system shall provide the capability to deliver batches of fuel and canister sludge samples to the 327 Building in batches of up to six fuel assemblies.

B. The system shall operate with present utilities available in the $K$ East and $K$ West Basin areas, and be able to operate with the existing physical environment (e.g., from existing grating, within overhead obstructions, weight restrictions, air quality, etc.) and the K Basin Safety Analys is Report (SAR).

C. Interfaces of support services (e.g., mobile laboratory), transportation (e.g., PAS-1 cask, CNS 1-13G cask), and 1aboratory handling (e.g., 222S, 327 Building) shall be fully defined and integrated in the system planning. Interface limits (e.g., dose rate, size, etc.) in each case shall be fully integrated. [This SDD does not cover the cask system. The cask system will be designed to interface with the acceptance criteria of the laboratory facilities chosen.]

D. The system shall be designed for routine use by $K$ Basin Operations staff. System controls and handling will account for the encumbrances on the operators wearing the levels of protective clothing needed in the $\mathrm{K}$ East and $\mathrm{K}$ West Basins.

E. The system and its operation will minimize waste and consider ease of disposal of waste throughout its life cycle (i.e., fabrication, operation, storage and final disposal of equipment). 
WHC-SD-SNF-SDD-005 Rev. 1

F. The system shall limit the amount of water added to either the KE or KW Basin during Phase II fuel sampling to 2000 gallons.

G. The system shall limit personnel exposure to five (5) person-rems for the entire gas/liquid, canister sludge, and fuel sampling campaign.

H. The system shall not require more than three (3) operators at any one time during fuel sampling and while preparing it for shipment.

1. Hydrogen generation from fuel and sludge samples shall not exceed 7 imits defined in WHC-SD-TP-SEP-028, N Reactor and Single Pass Reactor Fuel Characterization Shipments Safety Evaluation for Packaging, for the CNS cask (Crow 1996).

\subsection{GENERAL WORK PLAN AND K BASIN PLANT INTERFACES}

Figure 2 describes the general design sequence that was used for the SNF sampling system equipment. Basically, equipment development followed from the functions and requirements described in the previous sections. The cold test basin in the Hanford 305 Building was used as a key for assuring performance of the equipment (as much as possible through cold testing) and minimizing dose to operators and developers. The cold test facility was used for feature testing (e.g., independent testing of design features), design refinement, acceptance testing (i.e., final cold testing of the integrated system design with simulation), and cold training the $K$ Basin operators. Further validation of the operators followed in the $K$ West Basin to minimize dose (versus a dry run in $K$ East) while allowing final validation of the design in the actual environment of the Basin facilities.

The development of the readiness process was performed parallel to the development of the equipment using a graded approach for readiness as per DOERL directive 5480.31. Readiness documents (i.e., readiness checklist, work plan, procedures, etc.,) and safety reviews (i.e., hazards category, unreviewed safety questions, evaluations, etc.) for the sampling run were developed.

The interface and reviews between the design process of the equipment and the $\mathrm{K}$ Basin Operations Plant staff is summarized in Table 2. This approach was based directly on recommendations given in Administrative procedure 7-003-00 (WHC 1996), assuming a graded approach--combining related steps where feasible to simplify the effort for a relatively simple system. An example of this is the use of this SDD to provide four of the primary documents (e.g., documenting the SNFP need, functions and requirements, general work plan, and design description summary). This interface approach was reviewed with key $K$ Basin staff and should provide sufficient depth for the task involved. The Point of Contact (POC) will be continually advised on the design development steps as they occur.

Figure 3 shows the present work breakdown for development and first application of the SNF sampling system. Table l provides the primary 
documents, authors, and approving organizations. A detailed 1ist of these documents is given in Appendix B. Table 2 provides a summary of primary design areas and responsibilities. Because the first sampling was viewed as a high priority for input to process equipment design, the schedule for this sampling equipment made use of as many parallel activities and past design work as was reasonable. However, sound engineering, safety, ALARA, data quality, and $K$ Basin Operation requirements required a set of steps that could not be short cut for the sampling to be successful.

Since the sampling systems are to be run by operations, training of the operators was an important ingredient to success. Training was accomplished through (1) initial interface meetings on the equipment as it was designed and developed, (2) cold training in the Hanford 305 Building with the operators using the final equipment, and (3) a dry run made in the $K$ West Basin. Significant periods were allotted to these tasks to help assure the final application is successful with minimum dose.

The system and equipment for sampling canister sludge is described in WHC-SD-SNF-SDD-004, System Design Description for Sampling Sludge in $K$ Basins Fuel Storage Canisters (Baker 1996). The process and equipment are also described in this SDD to the extent necessary to integrate and show the relationships and interfaces between fuel sampling and canister sludge sampling.

\subsection{SYSTEM DESIGN DESCRIPTION}

The design of the sampling system is based in large part on concepts and equipment used in the 1994-95 fuel and sludge sampling campaigns. This system is designed to process SNF stored at KE Basin in open canisters and SNF stored at KW Basin in closed MkI and MkII canisters with the following features.

- The KE canisters are open at the top, allowing fuel to be removed out of the top of the canister.

- The KW MKI canisters are encapsulated using a piston-shaped lid with a Grafoi ${ }^{1}$ compression ring inserted into the top of the canister during initial encapsulation. The canister needs to be internally pressurized to drive out the lid and to allow fuel and sludge samples to be obtained from the top of the canister.

- The KW MkII canisters are encapsulated using an external cover secured with a locking bar. The locking bar is turned to remove the can and al low removal of fuel and sludge samples from the top of the canister.

The closed MkI and MkII canisters are provided with two external vent valves: one located in the center of the 1id, the other on the outer periphery of the lid. The center valve has a tube that extends $5.0 \mathrm{~cm}$ (2 in.) vertically down into the canister. The outer valve opening into the canister is flush with the inside of the lid. These two valves provide the capability

${ }^{1}$ Grafoil is a trademark of SEPCO Inc. 
to purge and fill the top two inches of the barrel with an inert gas when initially capping or recapping a canister, isolating a canister from the basin water. These two valves are also utilized to vent and completely fill the canister with water and to take gas and liquid samples.

As a result of the above differences, the equipment needed to sample SNF varies with type of canister. The equipment and their functions are summarized in Table 3 and are described in detail below. Minimum handling time is desired to maintain low worker dose rates. Materials used for construction of the equipment are compatible with the basin water and the radioactive gas, liquid, and fuel in the canisters. Unless otherwise noted, the equipment functions at the canister interface but is manually operated from locations above the basin grating. The heavier tools are equipped with lifting bails so that they can be moved using the basin monorail hoist system.

Gas and Liquid Sampler The function of the gas and liquid sampler is to sample the gas and/or liquid content of a closed MkI or MkII canister barre]. Access to the liquid contents inside the canister is through the center vent valve. Access to the gas contents inside the canister is through the side valve.

The sampler was designed to draw $20 \mathrm{ml}$ of gas or liquid samples from a canister. The sampler equipment is capable of opening a vent valve, drawing a sample, and closing the vent valve. The equipment was designed to prevent excessive sample dilution by basin water or cross contamination of samples. The first generation sampler system is shown in drawings $\mathrm{H}-1-80392$ and $\mathrm{H}-1-$ 80398. The holder rack used with this first sampler system is shown in drawing H-1-80405. The second/current generation sampler system is shown in drawings H-1-80399 and H-1-82347. The fuel canister rack that is used with the current system is shown in drawing H-1-80406.

Valve Stem Handling Tool The function of this tool is to open a vent valve from a MkI canister lid by loosening the valve stem. For the lid removal process, the tool is used to loosen the center valve stem of a MkI lid so that it can be removed from the valve using the air grip tool (supplied in the basins). The valve stem must be removed so that the pressure system tool can be threaded into the center valve to pressurize the canister. The design of this tool is shown in Drawing $\mathrm{H}-1-81198$. An alternate valve stem removal tool was designed to prevent loosening the entire valve body in case the valve stem has been overtightened. This alternate tool features a socket that fits over the valve body to hold it in place while an internal rod assembly loosens the valve stem. This tool is shown in Drawing $\mathrm{H}-1-82348$.

Tube Crimping Tool The function of this tool is to effectively close off the tube connecting the MkI canister barrel gas space to the gas trap. The tool does not have to completely close the flow path. However, the leak path should not contribute significantly to water addition to the basin. In addition, restricting the volume of flow into the canister will help prevent disturbing the sludge inside the canisters, which will improve the data quality of the sludge samples. The design of this tool is shown in Drawing H-1-81202. The tool was designed to provide roughly a 70:1 mechanical advantage, i.e., $90 \mathrm{~N}$ (20 1bf) applied to the handle will provide $6200 \mathrm{~N}$ (1400 lbf) of crimping force. 
Nut Handling Tool The function of this tool is to loosen MkI 1 id nuts during Tid removal (if necessary) and to tighten the nuts during lid replacement. The tool was designed to allow tightening to a torque of $40 \mathrm{~N}-\mathrm{m}$ ( $30 \mathrm{ft}-1 \mathrm{bf}$ ). The tool also features a universal joint assembly that allows a misalignment of about $\pm 5^{\circ}$. The design of this equipment is shown in Drawing H-1-81199.

Pressure system The function of this tool is to apply water pressure to the inside of MkI canisters via the center vent valve to gradually push the lid out of the canister. The system utilizes a booster pump that increases the inlet pressure by up to $830 \mathrm{kPa}(120 \mathrm{psig})$. The pump discharge flow, which varies with pressure boost, is approximately $25 \mathrm{~L} / \mathrm{min}(6.7 \mathrm{gpm})$ at $690 \mathrm{kPa}$ (100 psig) boost. The pump is only needed if the standard $\mathrm{K}$ Basin demineralized water supply is not capable of supplying sufficient pressure to remove a lid. Two pressure gauges are provided with the system: one pressure gauge monitors the pump discharge pressure, the second gauge monitors the approximate canister internal pressure (the pressure downstream of the contro? valve). The pump system connects to a pressurization tool via a hose and quick disconnect fittings. The design of this system is shown in Drawings $\mathrm{H}-$ $1-81200, \mathrm{H}-1-81204$, and $\mathrm{H}-1-82089$. The pressurization tool shown in Drawing $\mathrm{H}-1-81200$ is a previous design and will be used as a spare. The primary pressurization tool shown in $\mathrm{H}-1-82089$ was designed to reduce the flow restrictions (and subsequent pressure losses) through the tool such that a lid could be removed without crimping (if necessary). The pump configuration is shown in drawing $\mathrm{H}-1-81204$.

Lid Handling Tool The primary function of this tool is to install new MkI lids into the canister during recapping operations. The tool could also be used to pick up a MkI lid during removal, but normally the pressurization tool (H-1-82089) will be used to pick up and move the lid since it will already be connected for the lid removal process. The tool was designed to seat the lid such that the top of the lid is flush with the top of the canister cylinder after the lid nuts are tightened. The design of the MkI lid handling tool is shown in Drawing H-1-81197.

Scraper Tool The function of this tool is to remove excess Grafoil seal material from the inside of the canister, if necessary. If no significant amount of seal material remains inside a canister barrel after removing a lid, the scraper tool may not be required. This tool is shown in Drawing H-1-8120l. The scraper tool is essentially a modified MkI lid (with sharpened edges for scraping) adapted to the end of a T-handled pole.

Fuel Removal Tools This equipment is used to grapple and remove selected inner and outer fuel elements from canisters and place them in sample containers. The equipment prevents fuel from being 1 ifted to within $2.4 \mathrm{~m}$ $(8 \mathrm{ft})$ of the surface of the basin water. The fuel removal tools are shown in Drawings $\mathrm{H}-1-80543$ and $\mathrm{H}-1-80544$.

Fuel Canister Manual Valve Operators (Purge Tools) These tools are used with MkI and MkII canisters to (1) open and close the center and outer vent valves, (2) add water and corrosion inhibitor to recapped canisters, and (3) reestablish an inert gas space in the top of the canisters (purge the canisters). These too\}s are shown in Drawings $\mathrm{H}-1-51845$ and $\mathrm{H}-1-82344$ for MKII and MkI canisters, respectively. 
Single Fuel Element Containers (SFEC) This equipment is used to contain individual fuel samples taken out of the storage canisters. The containers are cylindrical and of sufficient diameter and length to hold an assembled inner and outer fuel element. One end is closed, and the other end is equipped with a removable, leak tight lid. The containers are capable of handling an internal pressure of $350 \mathrm{kPa}(50 \mathrm{psig})$. The 1id is provided with a small valve connection to permit hydrogen testing. This equipment is shown in Drawing $\mathrm{H}-1-80394$.

Hydrogen Tester This equipment will be used to measure the rate of hydrogen generation by measuring the rate of gas generation in the SFEC while it is stored near the bottom of the basin. Measurement of hydrogen generation is a necessary precursor to cask loading and shipping because it establishes the shipping window. This equipment is shown in Drawing H-1-81563.

Cask Insert This equipment is a cylinder with an internal structure designed to hold up to six SFECs or sludge canisters in a vertical position during transportation in the cask. This equipment is shown in Drawing H-1-81460.

Fuel/Sludge Transportation Cask (CNS 1-13G, or equivalent) The cask will be used to transport fuel and sludge samples held in the cask insert from the KE and $\mathrm{KW}$ Basins to the 327 Building. It is capable of being decontaminated before leaving the $K$ Basin. The support frame used for handling the cask lid in the basin is shown in Drawing H-1-80404. Detajled information on the transportation cask is given in WHC-SD-TP-SEP-028.

Gas/Liquid Sample Transport Systems These systems will be used to transport gas/liquid samples to the 2225 or 325 Building for isotope analysis. The PAS-1 cask may be used to transport these samples. More detailed information on the PAS-1 cask is given in WHC-SD-TP-SEP-033, Safety Evaluation for Packaging for the Transport of $K$ West Basin Canister Samples in the PAS-1 Cask. However, a less robust shipping system may be used depending on sample dose rates. [This SDD does not cover the cask transportation process.]

Canister Sludge Sampling System This equipment is used to sample sludge from open MkI or MkII fuel storage canisters. A sludge sample container is used to contain individual sludge samples and is transported using the same cask system as for SFECs. A more detailed description of this system is provided in WHC-SD-SNF-SDD-004.

Miscellaneous Tools and Support Equipment Several tools are required to support sampling operations. Lid lowering devices are used to lower a MkI or MkII lid from the basin grating level to a canister or lid stand on the basin floor. A lid stand was designed to hold a MkI or MkII lid so that it can be easily picked up with the Tid handling tools. Sketches of the support equipment are given in Appendix $A$. 


\subsection{SYSTEM OPERATION}

The KE Basin stores spent nuclear fuel in open canisters. The KW Basin stores fuel in canisters that are sealed by lids. The characterization process will include sampling fuel and sludge from canisters in both basins, but not necessarily both fuel and sludge from the same canister. Figures 4 and 5 are process flow diagrams for KE Basin and KW Basin, respectively.

The sequence of operation for fuel and canister sampling depends on the design of the storage canister being sampled. The most complex procedure is associated with the MkI sealed canister which has a piston lid that requires internal pressurization to remove. Of lesser complexity is the MkII canister which has an external lid secured with a locking bar. The least complex are the open canisters in the KE Basin which do not require gas and liquid sampling or need to be decapped. The primary steps in the basin sequence of operation are summarized in Table 4 and described below.

Sample Storage Canister Gas and Liquid Sampling of the gas and liquid content of capped storage canisters is needed to meet $\mathrm{DQO}$ requirements and as a screening technique for selecting canisters to be opened for fuel and/or sludge sampling.

The MkI and MkII canisters are provided with two vent valves on the top of the lid; one is in the center of the lid, the other is at the outer circumference of the lid. The center valve has an extension protruding approximately $5 \mathrm{~cm}$ ( 2 in.) down into the canister. These valves were used to add corrosion inhibitor to the canister water and to establish an inert gas space above the canister water and fuel when the fuel was encapsulated. These valves provide a means to sample the gas and liquid in the canister.

Pressurize MkI Storage Canister The MkI canister lid is basically a piston that is inserted into and fits flush with the top of the canister cylinder. The lid is sealed with a ring of Grafoil ${ }^{1}$ that is compressed. As a result of acceptance testing, the nuts used to compress the ring will typically not need to be loosened before the lid can be removed from its position in the canister cylinder (Roe 1996). If a 1id is to be reused, the nuts should be loosened prior to pressurizing the canister so that the lid can be easily reinstalled. Even with the nuts loosened, the lid will not slide out without appiying force, and therefore the inside of the canister is pressurized during decapping operations.

Pressurization will be done by first opening the vent valves to vent gas from the canister, and then injecting pressurized water into the canister through the center vent valve. Because of canister design pressure limitations, the injection pressure will be minimized, and is not expected to exceed $830 \mathrm{kPa}(120 \mathrm{psig})$. The MkI canister has a vent 1 ine connecting the top of the lid to the gas trap. This line will be crimped to effectively shut off the path for leakage of pressurized water into the basin and to 7 imit the flow of water into the canister to which could disturb the sludge inside the canister.

${ }^{1}$ Grafoil is a trademark of SEPCO Inc. 
Remove Storage Canister Lid The design of the MkI and MkII lids are different and require somewhat different procedures. After the MkI lid is pushed out of the canister cylinder by hydraulic pressure, the lid will be resting on top of the cylinder. It will then be lifted and set aside (away from the work area around the canister.) The MkII lid rests on top of the cylinder and is secured by a locking bar. The lid must be unlocked by loosening the nut and releasing the latching bar. It is then lifted and moved away from the work area. If a canister lid is not damaged, it may be reused. otherwise, a new lid will be installed in the canister. Damaged lids will be placed in containers and disposed of later using routine $\mathrm{K}$ Basin housekeeping procedures and equipment.

Remove Fuel Sample from Storage Canister The fuel stored in the K Basin and the subject of characterization is $N$ Reactor fuel consisting of two concentric fuel cylinders, i.e., an outer fuel element, and an inner fuel element. Two different sized mandrel collet systems, one to fit inside, expand and lift outer elements, the other to do the same with inner elements, will be used to lift fuel samples out of the canisters and place them into single element canisters or to perform visual examinations.

Recap Storaqe Canister New canister lids may be used when canisters are recapped depending on the condition of the existing lid. Recapping the canisters with new lids is not required. Much of the tooling to decap the canisters wi 11 be used during recapping operations. For installing a new 1 id on a MkI canister, the lid with Grafoil rings will be lowered into the basin using the lid lowering device (shown in Appendix A). The lid will then be picked up using the lid handling tool and inserted into the cylinder until the stops on the lid handling tool contact the top of the canister barrel. The three nuts will then be tightened to push the lid flush with the top of the canister and compress the Grafoil ring against the cylinder to seal the canister. In the case of the MkII canisters, the lid will be lowered into the basin, centered on top of the canister, and secured with the locking mechanism to seal the canister.

After the canisters are sealed, the vent valves may be used to add liquid corrosion inhibitor and establish an initial $5 \mathrm{~cm}$ (2 in.) inert gas space in the top of the canister. Note that this purging of the canisters is no longer required by the current $K$ Basin operational safety requirements document, WHC-SD-WM-0SR-006, and therefore is optional.

If necessary, the scraper tool will be utilized to remove excess Grafoil from the MkI canister sealing surface.

Load Single Fuel Element Containers and Test for $\mathrm{H}_{2}$ Fuel elements and fuel parts removed from storage canisters will be loaded into SFECs in preparation for loading into a shipping cask. The SFEC will be monitored for gas generation while it is in the basin.

Load SFECs into Transportation Cask The transportation cask will be lowered into the basin and prepared for insertion of the SFECs. A cask insert will be used to hold the SFECS in upright and approximately equally-spaced positions. Adequate steps will be taken to reduce contamination of the transportation cask (e.g., strippable paint). 
Prepare Cask for Shipment to the 327 Building The cask will be 1 ifted out of the main basin and the strippable paint removed. Any required protective overpack and shielding will then be installed. The cask will be installed and secured on a vehicle suitable for transporting heavy loads on Hanford Reservation roads.

Procedures and requirements for transportation of the cask to the 327 Building are described in WHC-SD-TP-SEP-028.

\subsection{SYSTEM LIMITATIONS, CASUALTY EVENTS, AND RESPONSE TO OFF-NORMAL EVENTS}

\subsection{MINOR OFF-NORMAL EVENTS}

The following events may occur during the course of fuel sampling and are considered to have minor consequences.

Basin Loss of Electric Power Response: This event could affect basin ventilation, basin hoists, and operation of electrically powered equipment associated with fuel sampling. If there is a loss of ventilation, further sampling steps will be stopped and personnel will respond in accordance with established $K$ Basin procedures for this type of event.

Events Involving the Gas/Liquid Sampler There are several possible minor events involving this equipment:

- Failed sampler Response: Pull out of basin and repair.

- Vent valve used for sampling fails to open Response: Use a separate vent valve tool (such as the tool shown in Drawing H-1-82348 for MkI lids) to loosen vent valve stem. If valve still fails to open, abandon attempts to obtain sample from the canister.

- Vent valve fails to close after sampling Response: Remaining gas in the canister may continue to vent into the basin. Notify the HPT.

\section{Events Involving the MkI Tools}

- Crimping tool fails to adequately crimp Response: Attempt to pressurize the canister to remove the 1id. An uncrimped tube should not affect the capability of the pressure system to push the lid out of the canister cylinder.

- Pressure system fails to remove 1id Response: Inspect the pressure system for damage and repair as required, otherwise abandon attempts to sample from the canister.

- Lid lowering device drops lid Response: Use the air grips (supptied in the basins) to retrieve 1 id.

Failure of 0ther Spent Fuel System Sampling System Equipment Response: Most of the equipment is designed to be operated from the grating level of the basin and can be taken up for repair. Plans for such repair will be made 
WHC-SD-SNF-SDD-005 Rev. 1

between 0perations and SNFE staff to optimize the process and mitigate ALARA concerns.

Local Electrical Power Loss Response: Put equipment in "standby" mode (i.e., power switches off, power disconnected, etc.) and under direction of PIC and Test Engineer leave area until power is restored.

Radiation Monitoring Instrumentation Failure Response: Sampling should be stopped and not resumed untiT PIC and Test Engineer and HPT supervisor are satisfied that adequate monitoring can be performed.

Evacuation of Facility Response: Sampling or preparations for sampling must be stopped as soon as the evacuation alarm sounds and the area evacuated. Equipment should be left with power disconnected. Any off-normal condition of the equipment must be communicated by the PIC to the shift or facility managers or other responsible staff, so the condition is clear to staff restarting the activity after the evacuation.

Spills and Leakage of Gas/Liquid Sample Response: Any spills or leaks will be evaluated by PIC and HPT and handled consistent with normal Basin practices (as appropriate, the shift and facility managers will be involved in the evaluation).

\subsection{SIGNIFICANT OFF-NORMAL EVENTS}

Overdilution of Gas/Liquid Sample Response: The sampler will be periodically tested using a reference source. If duration of overdiluted samples is significant, the sampler will be repaired and samples repeated as required.

\subsection{MAINTENANCE}

Most of the tools were designed to last the entire sampling campaign and therefore no maintenance is planned or scheduled. If a tool or other piece of sampling equipment fails or is damaged, plans will be made between operations and SNFE staff to repair or replace equipment as required.

For the gas and liquid sampler, reference samples will be taken to ensure that the equipment is functioning satisfactorily. The concern is overdilution of samples caused by excessive leakage around the seals. If a reference sample indicates equipment malfunction, then $\mathrm{plans}$ will be made between Operations and SNFE staff to perform maintenance on the sampIer equipment. 


\subsection{REFERENCES}

Baker, R. B., 1996, System Design Description for Sampling Sludge in K Basins Fuel Storage Canisters, WHC-SD-SNF-SDD-004, Rev. 1, Westinghouse Hanford Company, Richland, Washington, January 1996.

Crow, S. R., 1996, $N$ Reactor and Single Pass Reactor Fuel Characterization Shipments Safety Evaluation for Packaging, WHC-SD-TP-SEP-028, Rev. 1, Westinghouse Hanford Company, Richland, Washington.

Culley, G. E., 1995, K Basin S7udge Disposition Strategy, (letter, WHC9552284, to C. A. Hansen (RL), Apri1 24, 1995), Westinghouse Hanford Company, Richland, Washington.

Roe, N. R., 1996, Acceptance Test Report for $K$ Basin Mark I Lid Removal System, WHC-SD-SNF-TRP-017, Rev. 0, Westinghouse Hanford Company, Richland, Washington.

Siddoway, D. W., 1995, $K$ Basin Path Forward Action Items, (1etter, WHC9551459, to C. A. Hansen (RL), March 15, 1995), Westinghouse Hanford Company, Richland, Washington.

Stevens, P. F., 1995, Safety Evaluation for Packaging for the Transport of $K$ West Basin Canister Samples in the PAS-1 Cask, WHC-SD-TP-SEP-033, Rev. 0, Westinghouse Hanford Company, Richland, Washington.

WHC, 1995, Memorandum of Agreement on Path Forward for K Basin SNF, dated February 14, 1995, Westinghouse Hanford Company, Richland, Washington.

WHC, 1996, Administrative Procedure 7-003-00, K Basin Project Review Process, Westinghouse Hanford Company, Rich1and, Washington. 
Table 1. Documents Supporting Design and Application of $K$ Basin Fuel Sampling System.

\begin{tabular}{|c|c|c|}
\hline Name of Document & Author: & Accepting Organizations \\
\hline 1. Cold Feature Test Plan & SNFE & \\
\hline 2. Cold Acceptance Test Plan & SNFE & \\
\hline 3. Drawings & SNFE & \\
\hline 4. Preliminary Design Review Report & SNFE & KR-0, KR-1 \\
\hline 5. Final Design Review Report & SNFE & RR-2, KR-3 \\
\hline 6. Final Design Package for Equipment & SNFE & $\overline{\mathrm{KR}-3}$ \\
\hline 7. Training Plan & K Basin/SNFE & \\
\hline 8. K Basin Operating Procedures & K Basin/SNFE & \\
\hline 9. Master Work Plan & K Basin/SNFE & \\
\hline 10. Data Quality Objectives & SNFE & \\
\hline 11. Sample Analysis Plan & SNFE & \\
\hline $\begin{array}{l}\text { 12. System Design Description } \\
\text { SNFP Need } \\
\text { Function and Requirements } \\
\text { General Work Plan } \\
\text { Process Flow } \\
\text { Design Description }\end{array}$ & SNFE & KR-0, KR-1, KR-2 \\
\hline 13. QA Plan & QA/SNFE & \\
\hline 14. Waste Management Plan & K Basin & \\
\hline 15. ALARA Assessment & $\begin{array}{l}\text { K Basin + } \\
\text { SNFE }\end{array}$ & \\
\hline 16. USQ/Hazard Categorization & K Basin & \\
\hline 17. Readiness Assessment Checklist & K Basin/SNFE & \\
\hline 18. Job Hazards Analysis & K Basin/SNFE & \\
\hline 19. Cask SEP Mod (as needed) & Pak/SNFE & \\
\hline 20. Report Results First Run & SNFE & \\
\hline
\end{tabular}

\section{LIST OF TERMS}

SNFE:

SNFP:

KR-0, KR-1, KR-2, KR-3:

K Basin:

Pak:

QA:

ALARA:

USQ:

SEP:
Characterization Group Spent Nuclear Fuel Evaluations Spent Nuclear Fuel Project

$\mathrm{K}$ Basin Review Bodies

K Basin Operations Staff

Packaging and Transport Group

K Basin Quality Assurance Group

As Low As Reasonably Achievable

Unreviewed Safety Question

Safety Evaluation for Packaging

\section{NOTE:}

Detailed lists of drawings, supporting documents, and operating procedures associated with the fuel sampling system are provided in Appendices A, B, and C. 
Table 2. List of Primary Responsibilities.

\begin{tabular}{|l|l|l|}
\hline \multicolumn{1}{|c|}{ Organization } & \multicolumn{1}{|c|}{ Staff-Lead/Support } \\
\hline Cognizant Manager for Characterization & SNFE & R. P. Omberg \\
\hline $\begin{array}{l}\text { Characterization Program Interface, } \\
\text { Integration, and Data Requirements }\end{array}$ & SNFE/ES & D. W. Bergmann \\
\hline Data Quality Objectives & SNFE & $\begin{array}{l}\text { B. J. Makenas/ } \\
\text { L. A. Lawrence }\end{array}$ \\
\hline Sampling Analysis Plan & SNFE & R. B. Baker/T. L. Welsh \\
\hline Design Engineering of Equipment & SNFE & $\begin{array}{l}\text { A. E. Bridges } \\
\text { P. J. MacFarlan }\end{array}$ \\
\hline $\begin{array}{l}\text { Design and Application Interface between } \\
\text { K Basin and Characterization Group }\end{array}$ & $\begin{array}{l}\text { SNFE (Characterization) } \\
\text { K Basin (POC) }\end{array}$ & $\begin{array}{l}\text { D. W. Bergmann } \\
\text { C. D. Kirk }\end{array}$ \\
\hline Work Plan and Procedures & K Basin/SNFE & J. J. Jernberg \\
\hline $\begin{array}{l}\text { K Basin Safety Standards and Requirements } \\
\text { of the K Basin Organization }\end{array}$ & K Basin & R. G. Gant \\
\hline K Basin Safety of the SNFP Organization & K Basin & D. O. Hess \\
\hline Transportation of Samples & SNFE/Pak/K Basin & $\begin{array}{l}\text { S. A. Chastain } \\
\text { S. R. Crow } \\
\text { C. D. Lucas }\end{array}$ \\
\hline Training & & L. L. Blehm \\
\hline Quality Assurance & K Basin & R. W. Smith \\
\hline Air Permit & SNFQA & K Basin \\
\hline
\end{tabular}

\section{LIST OF TERMS}

SNFE: $\quad$ Spent Nuclear Fuel Evaluations Group

SNFP: $\quad$ Spent Nuclear Fuel Project

ES: $\quad$ Engineering Support Group

POC: $\quad$ K Basin Point of Contact

Pak: $\quad$ Packaging and Transportation Group 
Table 3. Equipment and Functions.

\begin{tabular}{|l|l|l|l|}
\hline \multicolumn{1}{|c|}{ Equipment } & KW Basin & KW Basin & KE Basin \\
\hline Gas/Liquid Sampler System & MkI Canister & MkII Canister & Open Canister \\
\hline Valve Stem Removal Tool & $\mathrm{x}$ & $\mathrm{x}$ & \\
\hline Tube Crimping Tool & $\mathrm{x}$ & & \\
\hline Nut Handling Tool & $\mathrm{x}$ & & \\
\hline Pressure System & $\mathrm{x}$ & & \\
\hline Lid Handling Tool & $\mathrm{x}$ & & \\
\hline Canister Scraping Tool & $\mathrm{x}$ (NOTE 1) & $\mathrm{x}$ (NOTE 1) & \\
\hline Fuel Removal Tools & $\mathrm{x}$ & & \\
\hline $\begin{array}{l}\text { Purge Tool/ } \\
\text { Fuel Canister Manual Valve Operator }\end{array}$ & $\mathrm{x}$ (NOTE 2) & $\mathrm{x}$ (NOTE 2) & $\mathrm{x}$ (NOTE 2) \\
\hline Single Fuel Element Canister (SFEC) & $\mathrm{x}$ (NOTE 1) & $\mathrm{x}$ (NOTE 1) & \\
\hline H Tester & $\mathrm{x}$ & $\mathrm{x}$ & $\mathrm{x}$ \\
\hline Cask Insert & $\mathrm{x}$ & $\mathrm{x}$ & $\mathrm{x}$ \\
\hline Fuel/Sludge Sample Cask & $\mathrm{x}$ & $\mathrm{x}$ & $\mathrm{x}$ \\
\hline Gas/Liquid Sample Cask & $\mathrm{x}$ & $\mathrm{x}$ & $\mathrm{x}$ \\
\hline $\begin{array}{l}\text { Canister Sludge Sampling Equipment } \\
\text { (WHC-SD-SNF-SDD-004) }\end{array}$ & $\mathrm{x}$ & $\mathrm{x}$ & $\mathrm{x}$ \\
\hline
\end{tabular}

\section{NOTES:}

(1) Two different tools are used depending on canister type, MkI or MkII.

(2) Two different tools are used depending on type of fuel, inner or outer element. 
Table 4. Sequence of Operation.

\begin{tabular}{|c|c|c|c|}
\hline & \multicolumn{3}{|c|}{ Basin } \\
\hline & \multicolumn{2}{|c|}{$\mathbf{K W}$} & $\mathbf{K E}$ \\
\hline Operation & Miki & Miki: & Open \\
\hline Move Storage Canister to Sampling Location & $\mathbf{x}$ & $\mathrm{x}$ & \\
\hline Sample Storage Canister Gas and/or Liquid & $\mathbf{x}$ & $\mathrm{x}$ & \\
\hline Load Gas and Liquid Samples into Transportation Cask & $\bar{x}$ & $x$ & \\
\hline Prepare Cask for Shipment to Laboratory & $\mathbf{x}$ & $\mathrm{x}$ & \\
\hline Pressurize Storage Canister & $\mathbf{X}$ & & \\
\hline Remove Storage Canister Lid & $\mathbf{x}$ & $\bar{x}$ & \\
\hline Remove Fuel and/or Sludge Sample from Storage Canister & $\mathbf{x}$ & $\mathrm{x}$ & $\mathrm{x}$ \\
\hline Load Single Fuel Element Canister (SFEC) and Test for $\mathrm{H}_{2}$ & $\mathrm{x}$ & $\mathrm{x}$ & $\mathrm{x}$ \\
\hline $\begin{array}{l}\text { Load Sludge into Sludge Sample Container and Test for } \mathrm{H}_{2} \\
\text { (WHC-SD-SNF-SDD-004) }\end{array}$ & $\mathrm{x}$ & $\mathrm{x}$ & $\mathrm{x}$ \\
\hline Recap Storage Canister & $\mathrm{x}$ & $\mathbf{x}$ & \\
\hline Move Canister Back to Storage Location & $\mathbf{x}$ & $\bar{x}$ & $\bar{x}$ \\
\hline $\begin{array}{l}\text { Load SFECs and/or Sludge Sample Containers into } \\
\text { Transportation Cask }\end{array}$ & $\mathrm{x}$ & $\mathbf{x}$ & $\bar{x}$ \\
\hline Prepare Cask for Shipment to 327 Building & $\mathrm{x}$ & $\mathbf{x}$ & $\mathrm{x}$ \\
\hline
\end{tabular}


Figure 1. Overview of $\mathrm{K}$ Basin SNF Canister Contents and Path Forward.

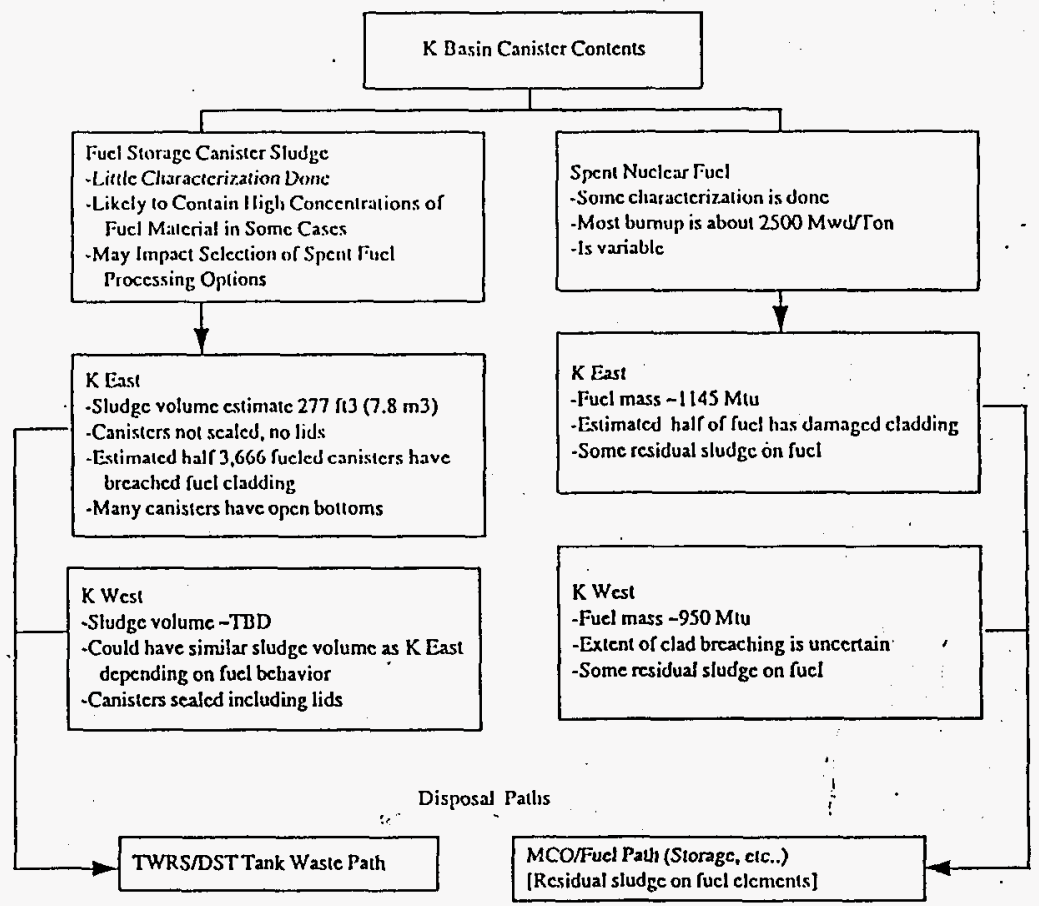


Figure 2. Proposed K Basin Plant Review of Fuel Sampling System Development and Application.

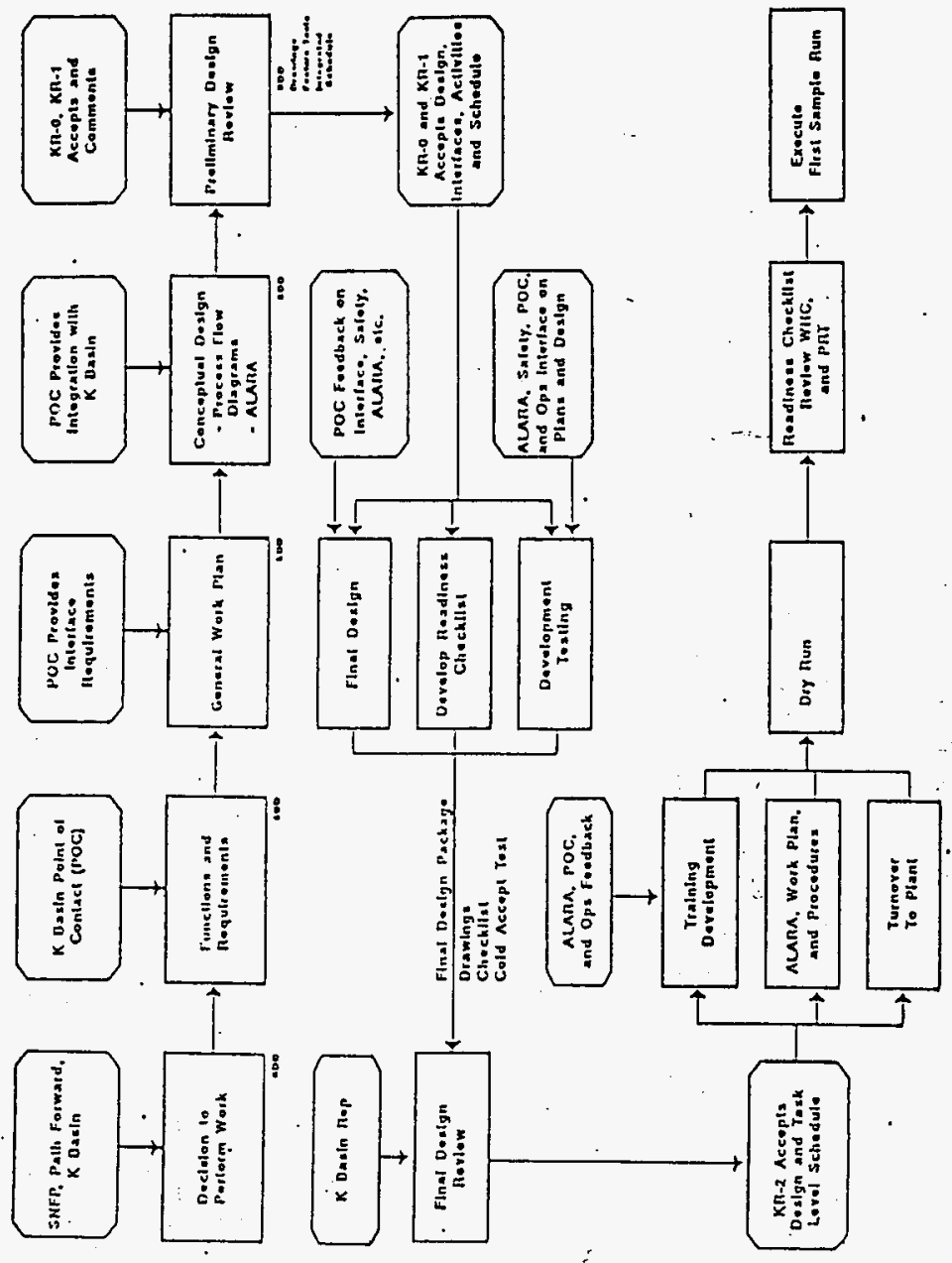



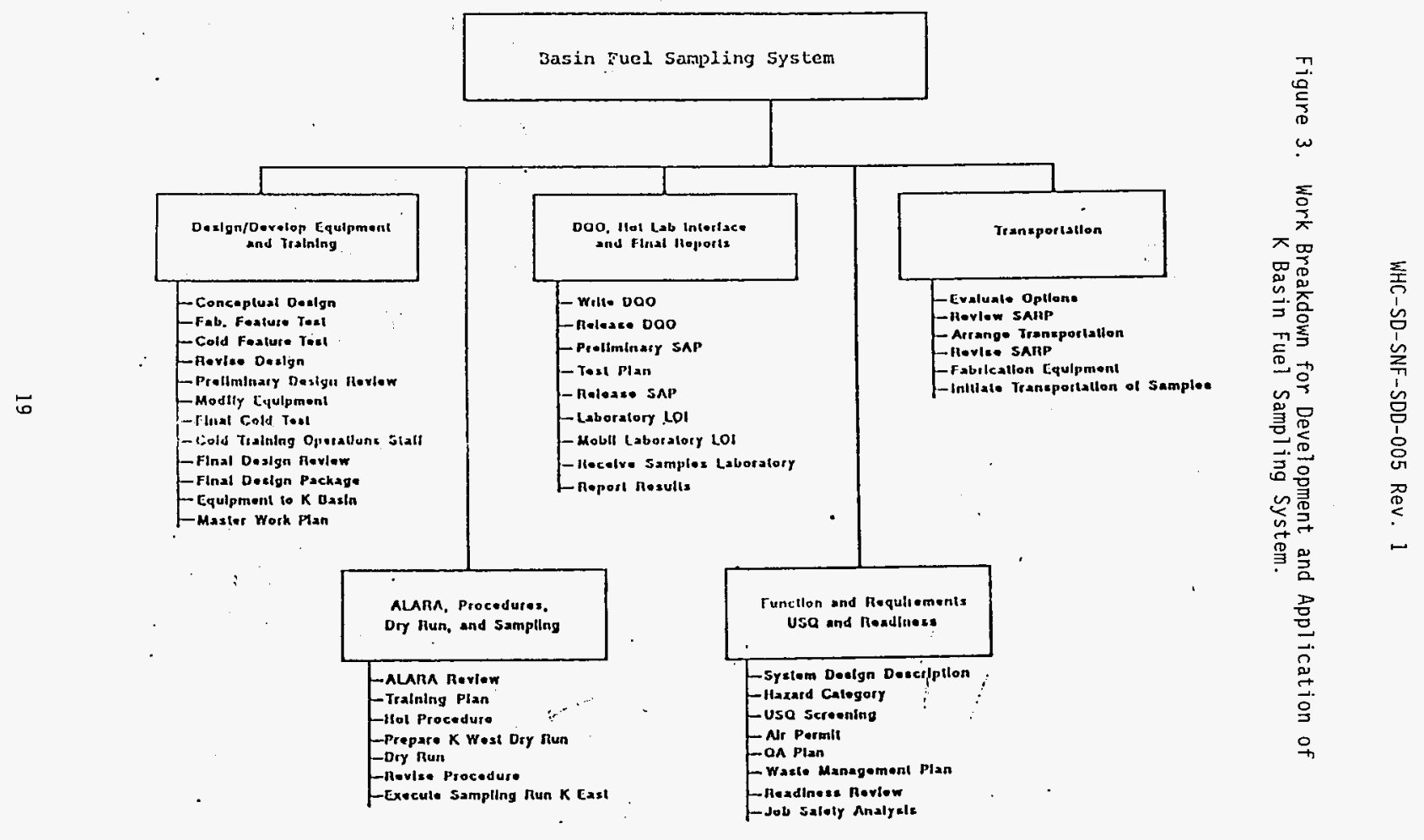


\section{K-EAST PROCESS FLOW}

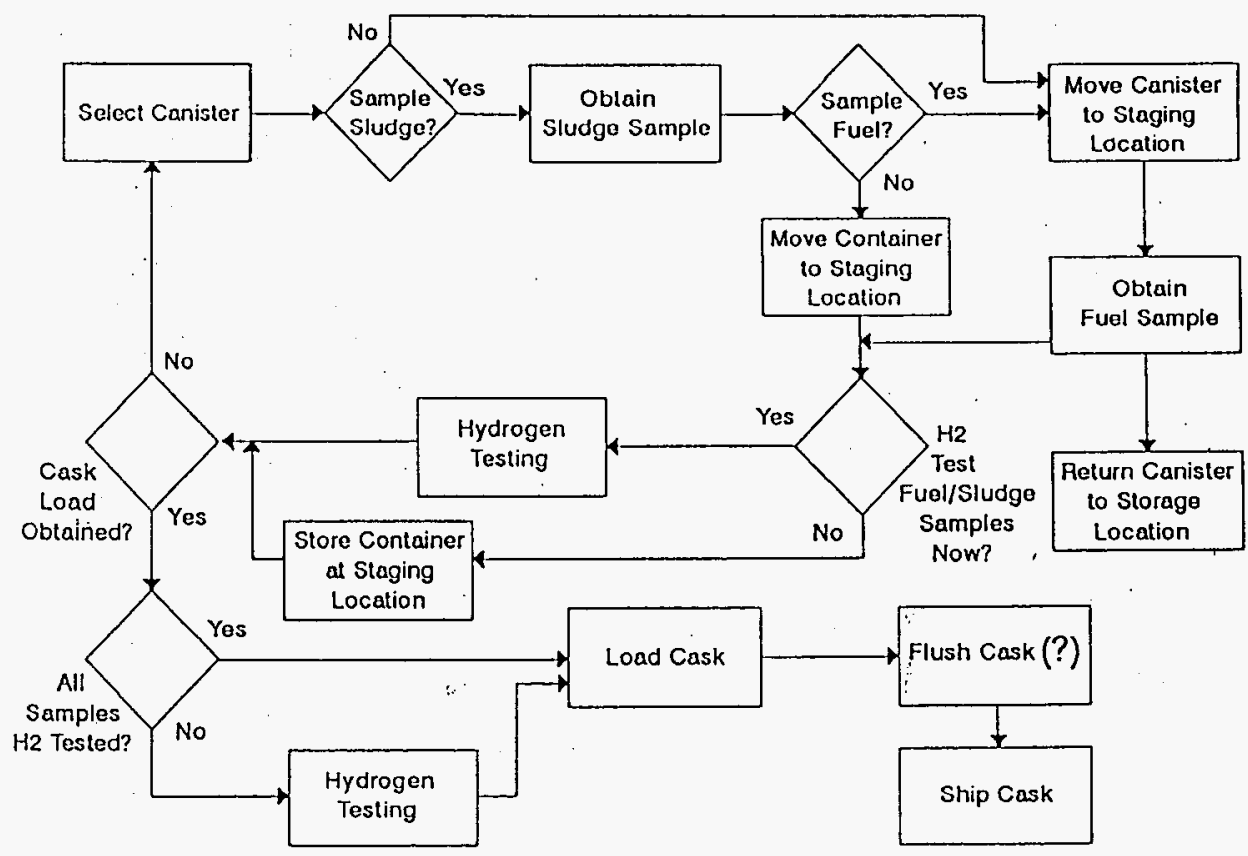


K-WEST PROCESS FLOW . G/L

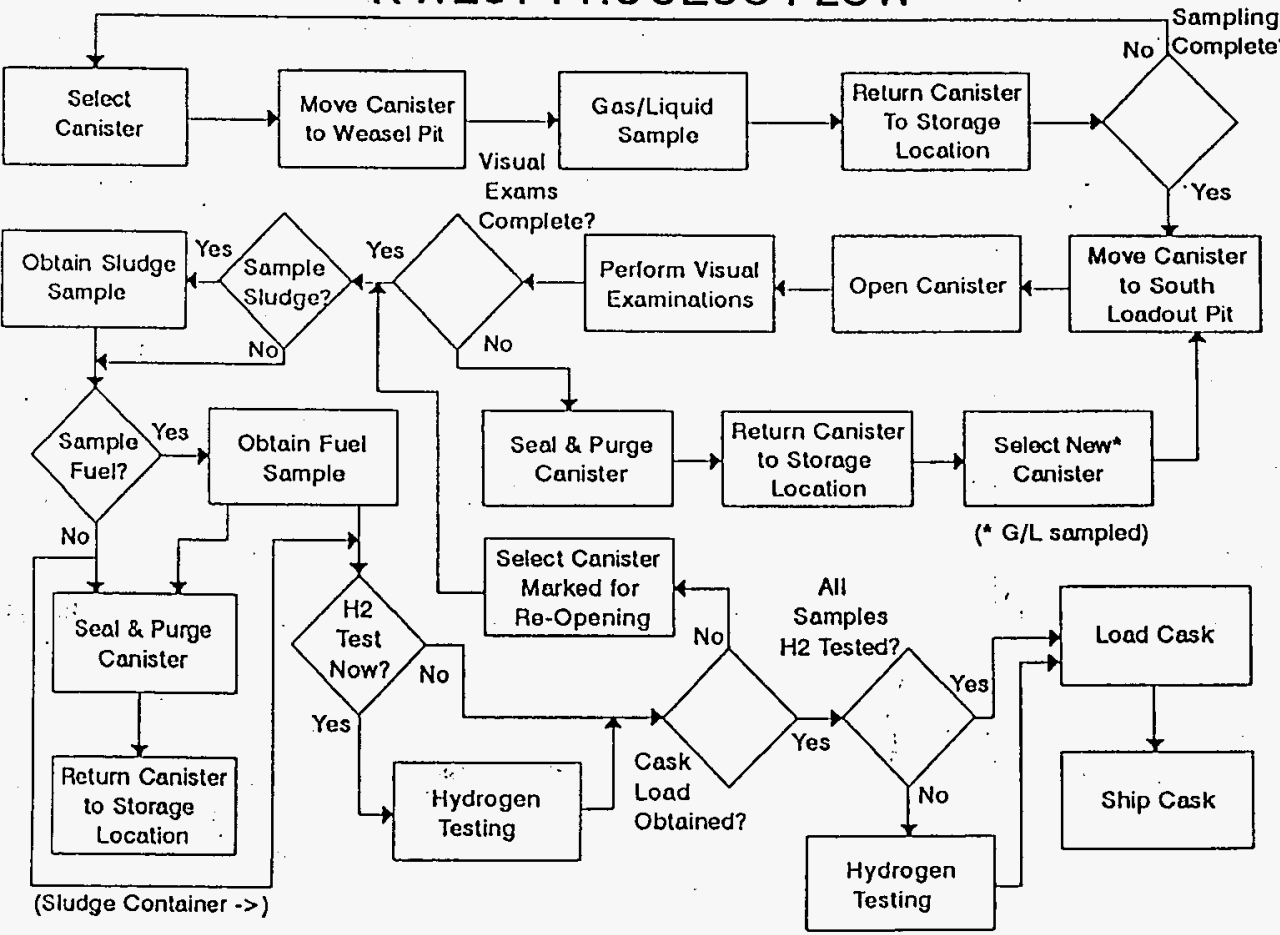


WHC-SD-SNF-SDD-005 Rev. I

APPENDIX A

DRAWING LIST AND SUPPORT EQUIPMENT SKETCHES

A-1 
The following is a 1 ist of drawings for the sampling equipment described in this SDD. Sketches of support equipment identified in this SDD are also provided in this Appendix.

DRAWING NUMBER

$H-1-80392$

H-1-80394

H-1-80396

H-1-80398

H-1-80399

H-l-81402

H- I-81404

H-1-81405

H-1-81406

H-1-80543

H-1-80544

H-1-81197

$H-1-81198$

H-1-81199

H-1-81200

H-1-81201

H-1-81202

H-1-81203

H-1-81204

H-1-81460

H-1-81563

H-1-81566

H-1-82089
IITLE

Fuel Canister Sampler - 1

Single Fuel Element Canister (SFEC)

Support Rack - Single Fuel Element Canister Arrangement

Sampler Bail

Fuel Canister Sampler - 2

Sampler Holder

CNS 1-13G Cask Lid Support Frame

105K Basin Fuel Canister Holding Rack

Fuel Canister Rack Assembly

Fuel Handling Tool Inner Element

Fuel Handling Tool Outer Element

MK-1 Lid Handling Tool Assembly

Valve Stem Handling Tool Assembly

Nut Handling Tool Assembly \& Details

Lid Removal Tool Pressure System Assembly

MK-1 Scraper/Cleaner Assembly \& Details

MK-1 Tube Crimping Tool Assembly

MK-1 Canister Gas Trap Assembly \& Details

MK-1 Lid Removal Pressure System Cart Configuration

CNS 1-13G Cask Liner Assembly and Details

Gas Sampler Assembly

Fuel Handling Tool Inner Element

MK-1 Lid Removal Tool Pressure System Assembly 
WHC-SD-SNF-SDD-005 Rev. I

MkI/II Lid Storage Stand Configuration

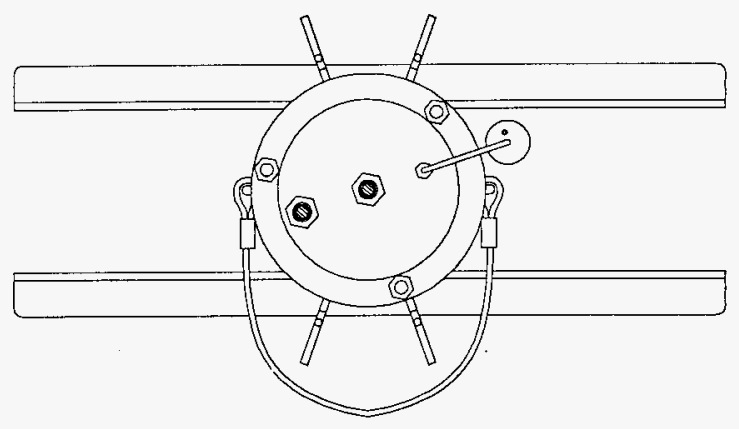

LID STDRAGE

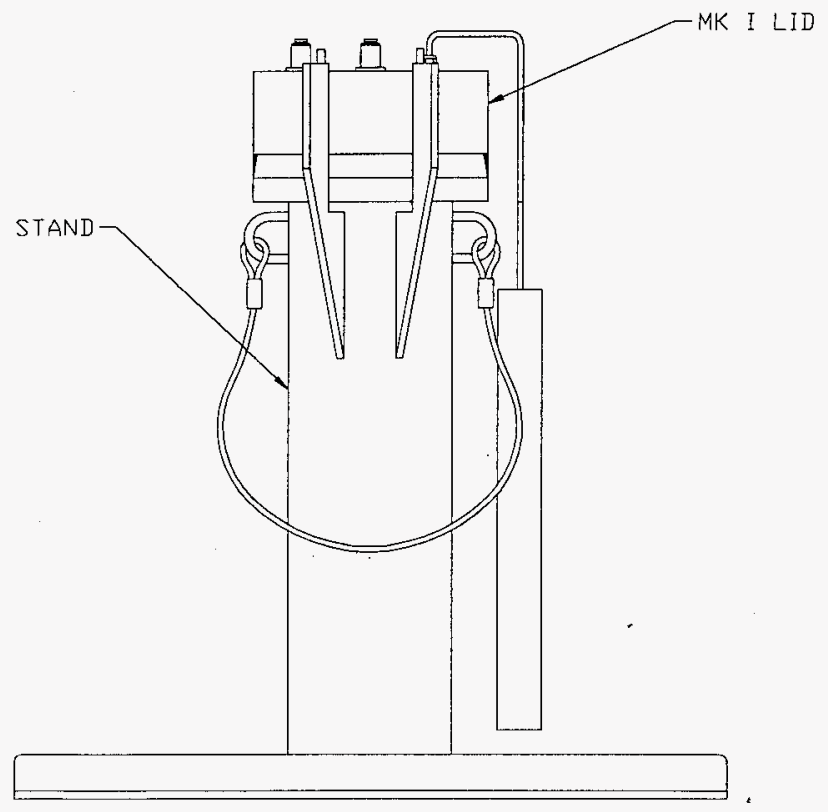


WHC-SD-SNF-SDD-005 Rev. 1

DRAWING NUMBER

\section{TITLE}

H-1-82344

MK-1 Canister Purge Tool Assembly

H-1-82347

$K$ Basin Fuel Canister Sampler General Arrangement

H-1-82348

Valve Stem Removal Tool Assembly

H-1-82349

K Basin Tool Storage Rack 
WHC-SD-SNF-SDD-005 Rev. I

MkI/II Lid Storage Stand Assembly \& Details

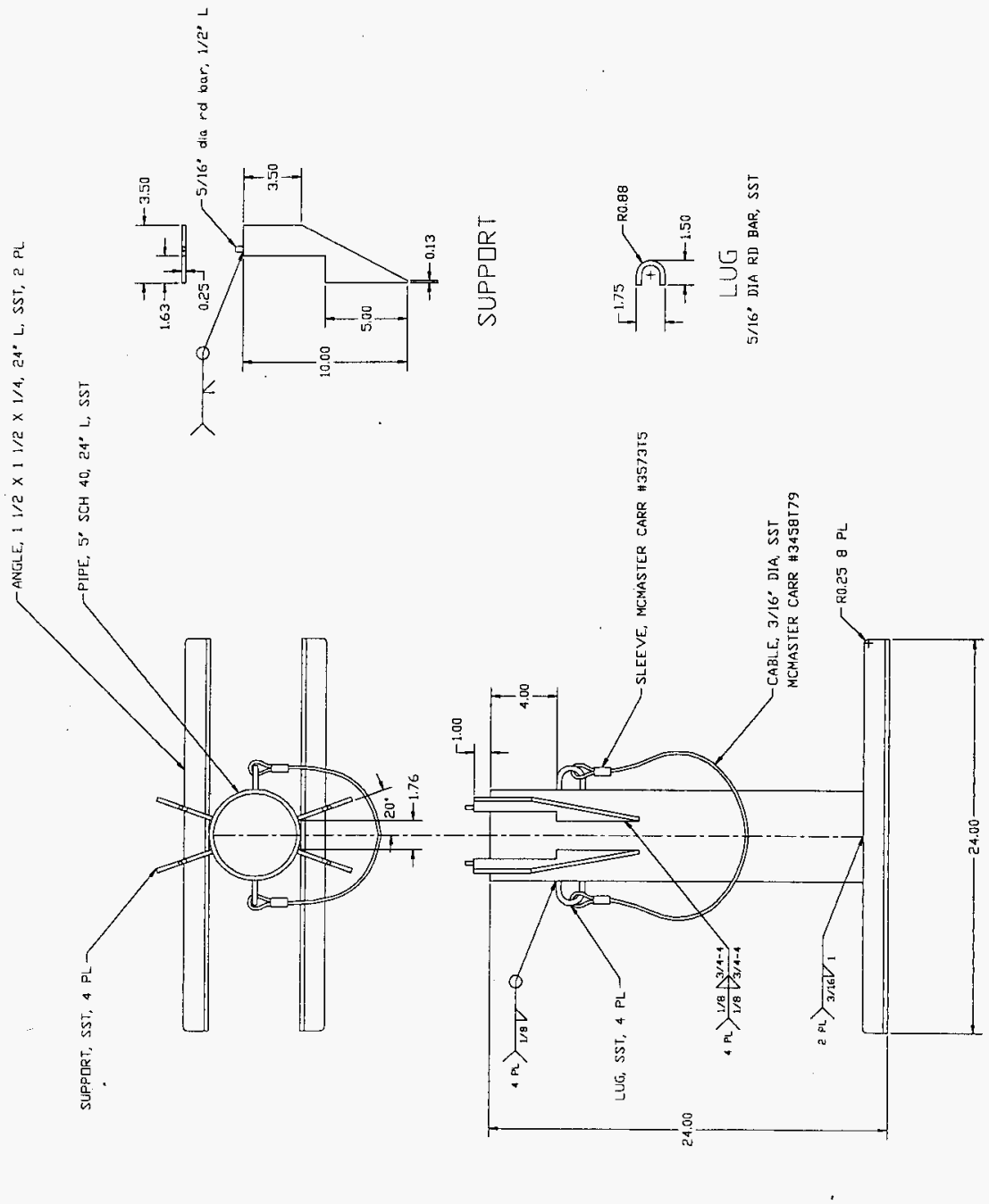


WHC-SD-SNF-SDD-005 Rev. 1

MkI Lid Lowering Device Configuration

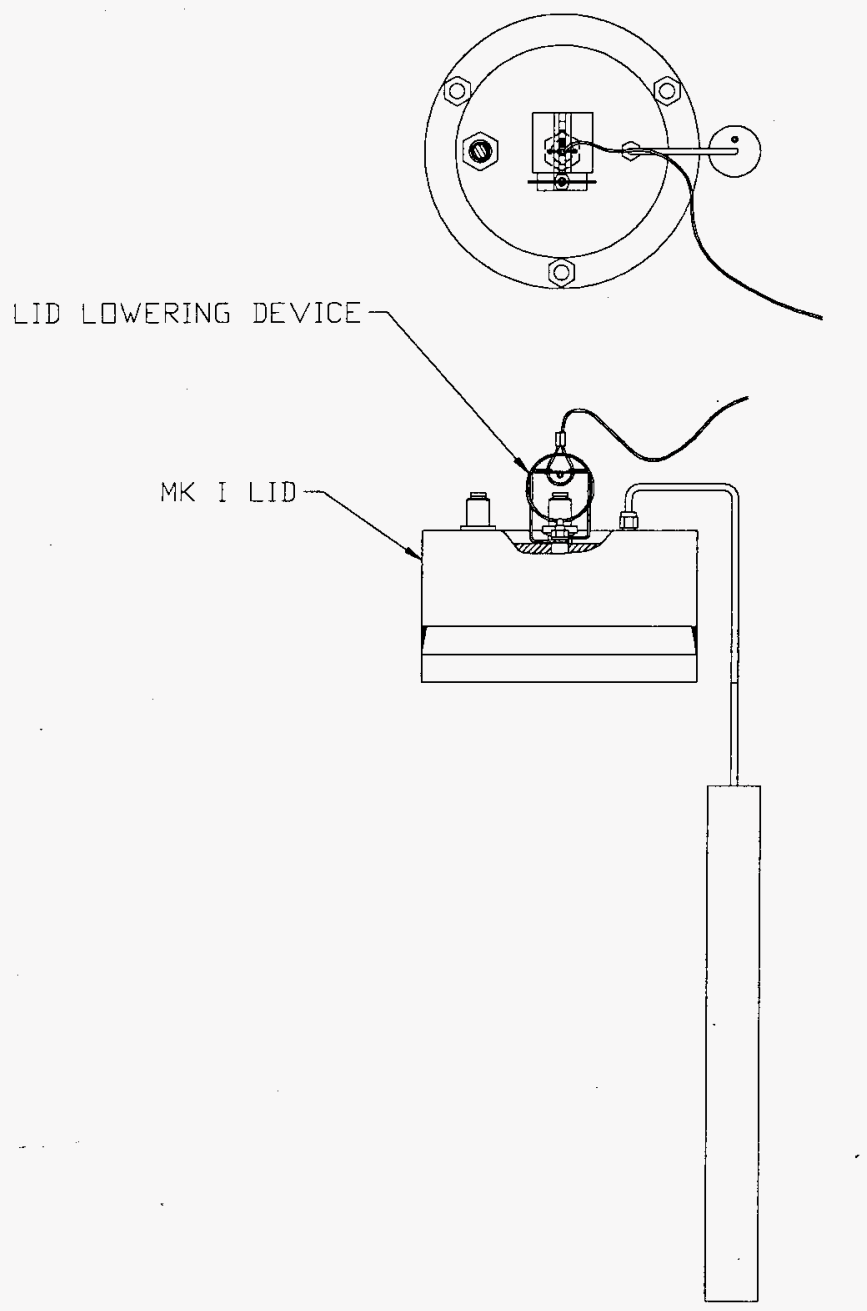


WHC-SD-SNF-SDD-005 Rev. I

MkI Lid Lowering Device Assembly \& Details

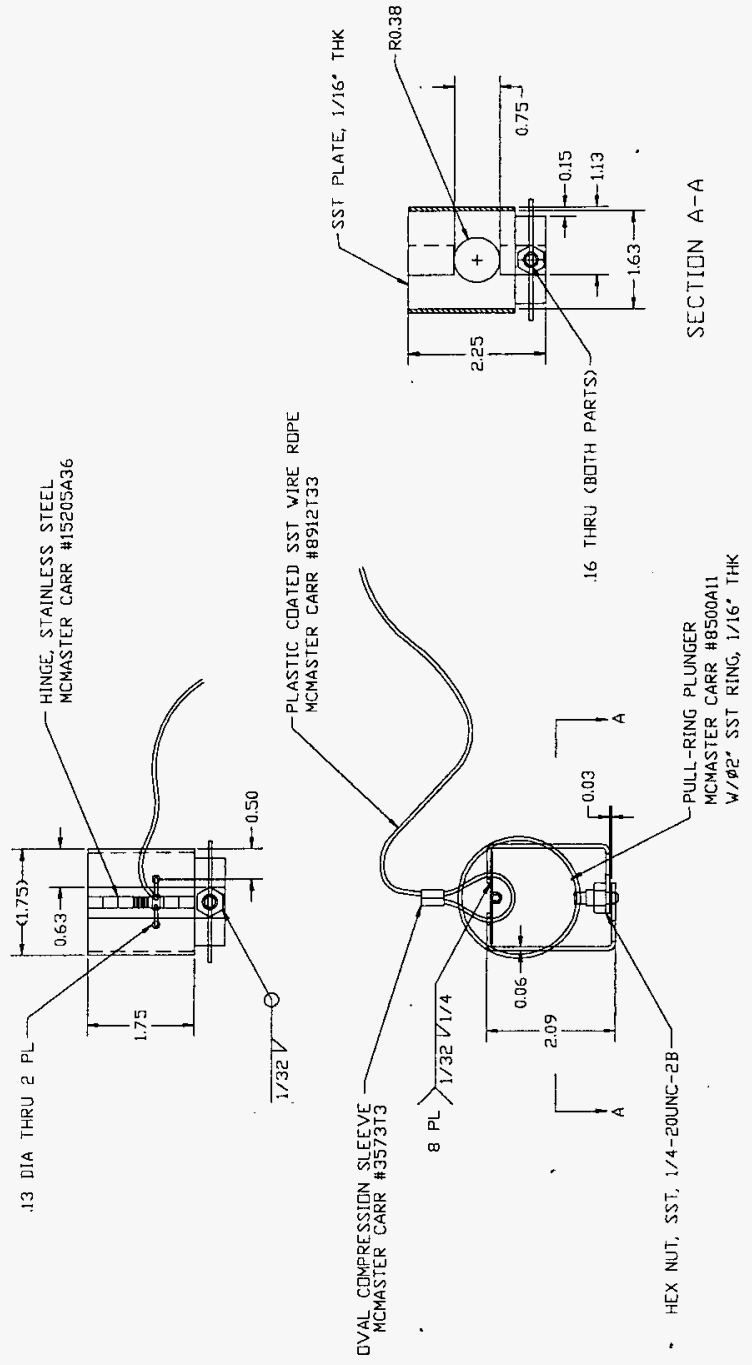


WHC-SD-SNF-SDD-005 Rev. I

APPENDIX B

SUPPORTING DOCUMENTS

B-1 


$$
\text { WHC-SD-SNF-SDD-005 Rev. } 1
$$

The following list provides the primary supporting documents identified in Table 1 of this SDD.

\section{TEST PLANS AND REPORTS}

WHC-SD-TP-TP-006

WHC-SD-SNF-TRP-017

WHC-SD-SNF-TP-010

WHC-SD-SNF-TRP-003

WHC-SD-SNF-TP-008

WHC-SD-SNF-TRP-002

WHC-SD-SNF-TP-030

WHC-SD-SNF-TRP-016

DRAW INGS

see Appendix A

DESIGN DOCUMENTS

WHC-SD-SNF-AP-001

WHC-SD-SNF-FDC-001

WHC-SD-SNF-DR-001
"Test Plan for K Basin Prototype Mark I Lid Remova] Tools," G. A. Ritter, June 1996.

"Acceptance Test Report for K Basin Mark I Lid Removal System," N. R. Roe, August 1996.

"Test Plan for $\mathrm{K}$ Basin Fuel Handling Tools," A. E. Bridges, February, 1995.

"Test Report for $K$ Basin Vertical Fuel Handling Tools," T. A. Meling, March, 1995.

"Gas/Liquid Sampling for Closed Containers in KW Basin Test Plan," C. C. Pitkoff, January 1995.

"Gas/Liquid Sampler for Closed Containers in KW Basin Test Report," C. C. Pitkoff, February 1995.

"Test Plan for Sealed Canister Gas and Liquid Sampling Equipment," D. J. Trimble, 1996.

"Test Report for Sealed Canister Gas and Liquid Sampling Equipment," D. J. Trimble, July 1996.
"Sealed Canister Liquid Sampling for Fuel Characterization Shipments," D. J. Trimble, January 1995.

"Gas and Liquid Sampling for Closed Canisters in KWest Basin Functional Design Criteria," C. C. Pitkoff, December 1994.

"Design Support Document for the $K$ Basins Vertical Fuel Handling Tools," A. E. Bridges, February 1995.

\section{TRAINING PLAN}

MWP-95-005 Appendix 1 "Fuel Characterization Phase II, Training P1an," J. A. Serles, March 1996.

\section{K BASIN OPERATING PROCEDURES}

see Appendix C 


\section{MASTER WORK PLAN AND OTHER WORK PLANS}

MWP-95-005

WHC-EP-0830

WHC-SD-SNF-WP-012

WHC-SD-SNF-WP-011

WHC-SD-SNF-PLP-010
"Fuel Characterization Phase II K-East \& K-West Basins," J. A. Serles, April 1996.

"Hanford Spent Nuclear Fuel Project Recommended Path Forward," J. C. Fulton, October, 1994.

"Gas and Liquid Sampling for Closed Canisters in $\mathrm{KW}$ Basin Work Plan," C. C. Pitkoff, February 1995.

"Work Plan for Development of $K$ Basin Fuel Handling Tools," A. E. Bridges, November 1994.

"Characterization Program Management Plan for Hanford K Basins," October 1995.

DATA QUALITY OBJECTIVES

WHC-SD-SNF-DQ0-001

WHC-SD-SNF-DQO-003

WHC-SD-SNF-DQ0-006

WHC-SD-SNF-DQ0-009

WHC-SD-SNF-DQ0-010

\section{SAMPLE ANALYSIS PLANS}

WHC-SD-SNF-PLN-004

WHC-SD-SNF-PLN-007

WHC-SD-WNF-SM-001

WHC-SD-SNF-SM-002
"Data Quality Objectives for the Initial K West Fuel Examinations," L. A. Lawrence, February 1995.

"Data Quality Objectives for Gas and Liquid Samples from Sealed K Basins Canisters," B. J. Makenas, March 1995.

"Data Quality Objectives for Gas and Liquid Samples from Sealed K West Basin Canisters (Second Campaign)," B. J. Makenas, July 1996.

"Data Quality Objectives for the $K$ East Fuel Examinations," L. A. Lawrence, February 1996.

"Choices of Canisters and Elements for the Second Fuel Shipment and Gas/Liquid Sampling from K West Basin," B. J. Makenas, 1996.

\footnotetext{
"Sampling and Analysis Plan for Canister Liquid and Gas Sampling at 105-KW Fuel Storage Basin," D. J. Trimble, August 1996.

"Plan for Characterization of $K$ Basin Spent Nuclear Fuel and Sludge," L. A. Lawrence, October 1995.

"Spent Nuclear Fuel Sampling Strategy," D. W. Bergmann, February 1995.

"Choices of Canisters and Elements for the First Fue 1 Shipment from K West Basin," B. J. Makenas, March 1995.
} 
WHC-SD-SNF-SM-003

WHC-N-1340 (logbook)

QA PLAN

WHC-SD-SNF-QAPP-006

WASTE MANAGEMENT PLAN

WMP-07-96

WHC-SD-SNF-PLN-001
"Choices of Canisters and Elements for the First Fuel and Canister Sludge Shipment from K East Basin," B. J. Makenas, March 1996.

"Fuel and Canister Sludge Characterization Phase II $K$ East \& K West Basins," Engineering Data Record, J. A. Serles, April 1996.

ALARA ASSESSMENT

8M730-RLS-96-002 (memo) "ALARA Assessment for K Basins Characterization Sampling and Shipping," R. L. Simons, March 1996 (appendix to the master work plan).

\section{USQ/HAZARD CATEGORIZATION}

WHC-SD-SNF-HC-011

USQ\# 1K-96-0015

WHC-SD-SNF-TA-002

WHC-SD-SNF-TA-003
"Fuel Characterization - Phase II Quality Assurance Activity Plan," G. M. Davis, February 1996.

"Fuel and Sludge Characterization for KW and KE," R. M. Jochen, February 1996.

"Waste Management Plan for Hanford Spent Nuclear Fuel Characterization," S. A. Chastain, October 1994. 
WHC-SD-SNF-SDD-005 Rev. 1

APPENDIX C

OPERATING PROCEDURES

C-1 
The following is a list of $\mathrm{K}$ Basin operating procedures used with the sampling equipment described in this SDD.

PROCEDURE NUMBER

OP-07-100E

OP-07-107E

OP-07-102E

0P-07-109W

OP-07-108W

OP-07-111W

\section{IITLE}

"Obtain Fuel Elements from 105-KE for Characterization," March 1996.

"Perform Visual Examination of KE Fue? in Support of Characterization," June 1996.

"Load Fuel and/or Sludge Containers into Chem Nuclear Shipping Cask," March 1996.

"Obtain Gas/Liquid Samples from MkI and MkII Canisters," August 1996.

"Obtain Fue 1 and Sludge Samples from MkI and MkII Canisters," August 1996.

"Load Fuel and/or S7udge Containers into Chem Nuclear Shipping Cask," August 1996. 